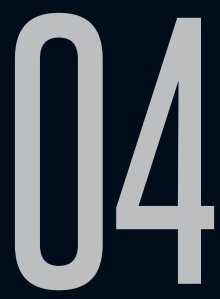

\title{
FIGURAÇÕES DO CORPO INSÓLITO EM PERSONAGENS DE SAMUEL BECKETT
}

Maria do Rosário Neto Mariano (UC)

Recebido em 29 set 2016. Maria do Rosário Neto Mariano: Professora Auxiliar Aprovado em 14 out 2016. de Literaturas e Culturas Lusófonas e Francófonas, na Faculdade de Letras da Universidade de Coimbra. Doutora em Literatura Francesa (UC, 2013), Mestre em Literatura Comparada (UC, 1988). Membro integrado do Centro de Literatura Portuguesa (UC), participa em projetos de investigação apoiados pela Fundação para a Ciência e Tecnologia.

Resumo: O presente estudo visa identificar, analisar e interpretar as figurações do corpo insólito em diversas personagens de obras teatrais e narrativas de Samuel Beckett. Essa categoria, o insólito, surge muitas vezes ampliada, de forma expressiva, por vertentes ou modalidades que vão desde o abjeto ou o absurdo, ao repugnante. Assim, o corpo surge sistematicamente diante do leitor-espectador como disfuncional, distópico e rebaixado até à abjeção mais ou menos repulsiva. Além disso, ele não se constitui como paradigma representativo de uma classe/grupo sócio-cultural, como perfil psicológico meramente individualizante ou, pelo contrário, identificativo de uma dada tipologia de indivíduos, como acontece nas personagens-tipo. Esse corpo é acima de tudo, e para além da sua materialidade hiperbólica quase expressionista, a figuração metafórica da condição 
humana universal, mas também marcada de forma muito particular pelas coordenadas desse período histórico que Elisabeth Angel-Perez designou por "pós-Auschwitz" ou "pós-ético".

Palavras-chave: Figuração; Personagem; Corpo; Insólito; Rebaixamento; Abjeção

Résumé: L'étude ici présente vise à identifier, analyser et interpréter les figurations du corps insolite dans plusieurs personnages parmi quelques oeuvres théatrâles et narratives de Samulel Beckett. Cette catégorie, l'insolite, apparaît souvent élargie de façon expressive moyennant quelques versants ou modalités qui vont de l'abject ou de l'absurde, jusqu'au répugnant. Ainsi, le corps surgit de façon systématique, devant le lecteur/spectateur, comme une réalité disfonctionnelle ou distopique et rabaissé jusqu'à l'abjection plus ou moins repoussante. Par ailleurs, ce personnage n'est pas à proprement parler un paradigme représentant, soit une classe ou un groupe socio-culturel, soit le profil psychologique d'un individu quelconque ou, au contraire, identifiant une certaine typologie d'individus, comme il arrive chez les personnages-types. Ce corps est par-dessus tout, et au delà de sa matérialité presque expressionniste, la figuration métaphorique de la condition humaine universelle mais marquée, de façon toute particulière, par les coordonnées et les fantômes de cette période historique que Élisabeth Angel-Perez a désignée comme "post-Auschwitz" ou "post-éthique".

Mots-clés: Figuration; Personnage; Corps; Insolite; Rabaissement; Abjection

A obra do autor convocado no presente estudo não se filia numa conceção mimética ou representacional da ficção literária relativamente à realidade empírica, nas suas múltiplas vertentes, designadamente o espaço, o tempo, o contexto social 
e histórico ou epocal mais ou menos detalhado, os perfis físicos e psicológicos convenientemente identificados e analisados, enfim, os enredos relativamente complexos que desenham existências individuais e coletivas.

Na sua ficção teatral e narrativa, estamos perante uma espécie de estética do claro-escuro, do dito arrebatado ao indizível, quer por meio da palavra hesitante, balbuciante e apoiada numa gestualidade fortemente impressiva (sobretudo na ficção teatral), quer através da palavra torrencial, mas obedecendo a uma lógica fragmentária, caleidoscópica (dominante na ficção narrativa). Tais características exigem do leitor, com alguma frequência, a elaboração de uma estrutura dotada de uma orgânica e uma temporalidade mais propícias à inteligibilidade diegética, ainda que premeditadamente os textos permaneçam lacunares na resposta a múltiplas indagações.

Por seu lado, o quase sistemático rebaixamento do corpo nas personagens beckettianas manifesta-se em figurações hiperbólicas de natureza disfórica, ampliações de cariz quase expressionista que parcialmente as esvaziam daquela referencialidade verosímil mais imediata, própria do Realismo literário e correntes afins.

Porém, num outro sentido, pode falar-se de um eficaz realismo metafórico relativamente a estas figurações do corpo, extensível, aliás, aos adereços e espaço físico que o ampliam, redimensionando a perceção e as competências sensoriais do recetor, no tocante aos mais negros e angustiantes aspetos da condição humana e do contexto civilizacional em que se inscreve a obra de Beckett ${ }^{1}$.

1 É de realçar, porém, que não deverá assimilar-se a designação de "realismo" aqui utilizada por Adorno, às características e finalidades associadas ao realismo canónico, tal como o encontramos representado na ficção literária de um Eça de Queirós, de um Flaubert ou de certa literatura neorrealista. 
On dit toujours de Beckett qu'il pratique une technique de réduction extrème [...] Mais cette réduction, c'est déjà réellement "ce que le monde fait de nous", pour reprendre l'expression de Karl Kraus. Ces restes mutilés d'homme, ces hommes qui ont en fait perdu leur moi, sont de véritables produits du monde dans lequel nous vivons. [...] II est réaliste, j'y tiens, dans la mesure où, à travers ces figures qui sont aussi des restes mutilés et représentent quelque chose de général, il est l'interprète précis de ce que deviennent tous les individus une fois réduits à n'être que de simples fonctions d'un ensemble social universel. (ADORNO, 2008, p.119)

Como boa parte das personagens literárias, estas possuem relevantes virtualidades cognitivas e acentuada densidade semântica. Contudo, é sem dúvida menos evidente a sua dimensão pragmática imediata — mais própria dos Realismos -, na qual a dinâmica transficcional, tão operante, por exemplo, no teatro ou no romance de costumes, permite um reconhecimento bem mais direto, por parte do leitor/espectador, das componentes psicossomáticas inscritas na figuração das personagens e na modelização dos seus discursos, quer ele seja ou não contemporâneo contexto históricosociológico ficcionalizado.

No âmbito desta questão, e referindo-se à figuração realista patente em várias personagens queirosianas, escreve Carlos Reis: "[...] elas significam alguma coisa para o leitor, porque a figuração impõe a dinâmica transficcional que leva a reconhecer aqueles componentes psicossociais como fazendo parte do mundo do leitor" $(2015$, p.29) 2 .

2 Para uma compreensão mais detalhada dos aspectos relacionados com o que o autor designa por "figuração ficcional", veja-se Reis, 2006; Eder et alii, 2010. 
A designada dinâmica transficcional, bastante fluida na ficção realista ou naturalista de oitocentos, por exemplo, é já mais problematizante face às modalidades de figuração das personagens e do espaço que as prolonga ou ajuda a definir, relativamente à ficção beckettiana. Com efeito, as suas figurações, particularmente as do corpo, embora longe do abstracionismo surrealista ou de um certo hermetismo de cariz simbolista, estabelece, sem dúvida alguma, fortes ruturas parciais com os horizontes empíricos habituais do leitor/espectador, devido à componente de insólito nas suas variantes de estranho, absurdo ou abjeto - que a estrutura e dimensiona, nos planos sensorial, semântico e igualmente na indagação transficcional criada pelo insólito em si mesmo.

Não obstante, neste estudo, e como atrás foi já sugerido, parte-se do postulado de que nenhuma ficção literária é autotélica, fechada sobre a sua distintividade formal e semântica ou sem relação dialética com a realidade empírica e o contexto históricocultural em que se originou.

No que àquela relação dialética diz respeito, trata-se antes de uma diferença de graus: ela é menos fluida ou mais complexa quando a componente de insólito está presente, aspeto que se acentua, logicamente, em ficções literárias pertencentes ao género fantástico.

Ora, alguns dos traços mais relevantes das figurações do corpo em personagens beckettianas advêm justamente do insólito, também presente na noção de corpo fantasmático desenvolvida por Marie-Claude Hubert. (1987, p.91-95)

Esta modalidade de figuração ficcional surge no contexto das grandes e impressivas metamorfoses sofridas pela personagem, 
a partir da década de cinquenta do século $X X$, na sequência dos dramáticos acontecimentos históricos e mutações ideológicas que se haviam verificado no decurso da primeira metade do século (ABIRACHED, 1978).

Refletindo sobre a noção de ficção do insólito e, mais concretamente, sobre "figurações do insólito em contexto ficcional", Carlos Reis refere:

[...] é pertinente falar no insólito no insólito em confronto com a ficção a que chamamos realista. Para ser adequadamente descrito, esse insólito deve ser observado tendo-se em atenção a lógica do realismo e mesmo, de certa forma, a necessidade de se agir contra essa lógica. (2015, p.97)

No quadro ficcional beckettiano, o corpo das personagens é quase sempre objeto de uma estratégia e de uma estética do rebaixamento até ao insólito, figurado em múltiplas disfuncionalidades, deformações, deficiências, limitações dos membros locomotores e de certas funções vitais, constituindo uma espécie de galeria pós-expressionista de figuras-limite e, simultaneamente, uma poderosa metáfora da condição carcerária do ser humano no mundo e no seio de toda e qualquer comunidade familiar ou social.

Enclausurados, segregados, supliciados ou paralisados, tais corpos constituem-se como verdadeiros túmulos fisiológico-anatómicos da sua própria vitalidade orgânica. Daí as metáforas espaciais sugeridas por adereços de natureza carcerária: jarras, ânforas, sacos, catres, cadeiras de rodas, buracos na terra; eles contêm e imobilizam os corpos, ora exibindo a sua morfologia disforme, ora anulando-os pelo 
parcial sepultamento, impedindo-os quase totalmente do exercício dessa autonomia necessária à realização de múltiplos projetos ou à prossecução de ações consequentes. ${ }^{3}$

Não podendo evidentemente considerar aqui todas as obras do autor paradigmáticas destas figurações do corpo das personagens, partirei das seguintes obras (em língua francesa ou em tradução portuguesa): Comédie; Dis, Joe; Acte sans Paroles II; Dias Felizes; Malone está a morrer; Novelas e Textos para nada.

Observe-se textualmente o caráter insólito da seguinte Indicação cénica de abertura, na peça Comédie:

A l'avant-scène, au centre, se touchant, trois jarres identiques, un mètre de haut environ, d'où sortent trois têtes, le cou étroitement pris dans le goulot. [...] Elles restent rigoureusement de face et immobiles d'un bout à l'autre de l'acte. Visages sans âge, comme oblitérés, à peine plus différenciés que les jarres. (BECKETT,1972, p.9)

Veja-se, ainda, o protagonista da novela $O$ Banido, narrador autodiegético de uma existência sub-humana, de rejeição ou punição cruéis e bestializantes por parte daqueles que com ele se cruzam:

Não pude levantar-me à primeira tentativa, nem, digamos assim, à segunda, e mal me pus finalmente de pé, e encostado à parede, pensei se iria poder ficar assim [...] sair e andar, era impossível. [...] Já não estou em casa daqueles assassinos, naquela cama de terror, mas no meu refúgio longínquo, de mãos atadas, cabeça curvada, fraco, ofegante, tranquilo. (2006, p.30)

3 Sobre esta problemática da condição carcerária em protagonistas/anti-heróis de Beckett e outros autores contemporâneos, veja-se a interessantíssima obra de Jerry L. Curtis, 1994; e ainda Didier Anzieu, 1996, p.123-131. 
Nos mimodramas, como é o caso de Actes sans Paroles II, a própria linguagem, instrumento de humanização, é omitida, retirada de cena, dando lugar à mera expressão brutal ou histriónica do corpo, ainda assim, intermitentemente sitiado.

Globalmente, o corpo das personagens beckettianas é investido de uma extrema organicidade, opaca e opressiva, ao mesmo tempo que as suas figurações transgridem claramente os códigos representacionais da ficção literária realista. Assim, descrições ou figurações identificadoras do rosto desaparecem nas obras do autor, ausência que, voluntária e metaforicamente, acentua o dramatismo da perda de individualidade, a alienação do ser humano pelo apagamento da pessoa singular na indiferenciação das massas.

Em Comédie, a figuração do insólito e do fantástico coexiste, porquanto as personagens, encerradas em vasos tumulares verticais que só permitem mostrar vagamente os rostos, monologam a partir de um espaço-tempo penumbroso vindo do além-morte, que identificam como a continuação do inferno de pensar, sendo, portanto, uma condição opressiva - espécie de "huis-clos" sartriano e de desassossego pessoano, a um tempo - na qual redenção e fuga se revelam igualmente inviáveis.

Esta omissão de figurações do rosto personalizado, relativamente às personagens, decorre da própria lógica antipsicologista que norteia a obra do autor. Com efeito, descrever e caracterizar rostos e expressões faciais na ficção literária implica seguir uma estratégia de valorização da análise psicológica e/ ou de individuação sociológica que identifique, por exemplo, os 
protagonistas de uma dada obra, facultando ao leitor instrumentos complementares de descodificação diegética.

Destes rostos ausentes ou neutros dimana, contudo, uma voz, dialogal ou monologal, mas quase sempre refém da surdez física ou mental do interlocutor, como acontece nas peças Dis Joe e Dias Felizes. Por vezes, esses longos monólogos causam no leitor/espectador sensações de estranheza que confinam com o fantástico ou o absurdo, seja por surgirem no contexto de um quarto fechado como uma espécie de emanação do além-morte na consciência parcialmente entorpecida da personagem (Di Joe), seja porque interminavelmente a protagonista recomeça cada dia o seu discurso, mesmo estando consciente de que ele raramente alcança o destinatário presente-ausente, seu improvável companheiro, persistindo na sua litania com uma bonomia próxima do absurdo ou, no limite, da beatitude (Dias Felizes):

L'univers théâtral de Beckett désarçonne le spectateur en le plongeant dans un insolite radical. Les repères du sens sont brouillés et três vite on s'aperçoit qu'il est vain de chercher à construire le sens avec les outils habituels de I'herméneutique ou de la logique. [...] Même réduit à l'état larvaire, même invisible, le corps émet vocalement: il vocalise et c'est là sa tragédie. (ANGEL-PEREZ, 2006, p.37-41)

Nesta peça - uma das obras-primas do autor - as duas únicas personagens surgem diante dos espectadores/leitores numa situação cénica cuja inverosimilhança apenas se coaduna com a lógica do insólito; para além de a sua figuração estar intimamente associada ao elemento terra, ela é parcialmente construída a partir 
de uma metáfora zoomórfica - a condição rastejante, quase reptiliana da personagem masculina, Willie - , e de uma metáfora botânica - Winnie, a personagem feminina, qual arbusto, encontrase presa na terra até ao tronco (I Ato) e até ao pescoço (II Ato).

Winnie surge, assim, com o corpo quase inerte, a mente frágil e de ténues recursos face às suas próprias indagações sobre o sentido da existência individual, encontrando-se já quase parcialmente fundida com a elementaridade ctónica e passiva da terra daquela tundra-tumba. Nessas circunstâncias, vai aceitando o seu quotidiano moroso e sem horizontes, o lento purgatório da sua imobilidade e da pré-demência senil do seu companheiro. A gesticulação dos braços, de movimentos ora vivos e estilizados, ora lentos e recorrentes, é acompanhada de um discurso perturbador, de uma complacência fatalista face ao papel aleatório de cada ser humano num universo de que desconhece as causas e os fins.

Num estudo singular dedicado a esta peça, Armando Nascimento Rosa afirma:

E o melancólico de que fala este feminino disfarce de Beckett é sem dúvida o dia alegórico onde toda uma vida humana está contida. Metáfora da existência material é o destino de Winnie: enquanto vivos, a terra clama pelos nossos corpos e os dias, da vida que se sucede, correspondem já a um préenterramento simbólico, que a personagem expõe como um animado fresco. A terra não é entendida no prisma da fertilidade germinativa, já o sabemos, mas sim no da fatalidade tumular, partilhada por todos os seus habitantes serem seres-para-amorte. Verificamo-lo quando Winnie descreve a ausência de plantas no espaço que o ver alcança. (2000, p.27) 
Numa das falas mais marcantes da protagonista, está patente a aspiração fatigada à redução ao corpóreo, à rude matéria da carne dos animais para abate, dessa elementar inconsciência de todos os seres vivos que não conhecem o peso da lucidez, da angústia e, sobretudo, da coragem para o suster quotidianamente, conscientes de que esse esforço deveria manter-se indefetível até ao fim dos dias, mas que será, enfim, vencido, rebaixado na sua humana dignidade:

E se, por razões obscuras, o mais pequeno esforço deixasse de ser possível, então é só fechar os olhos (Fecha-os) e esperar que o dia chegue (Abre os olhos), o dia feliz em que a carne se derrete a tantos graus e a noite de luar dura tantas centenas de horas. (Pausa). Eis o que eu acho reconfortante, quando perco a coragem e começo a invejar a sorte dos animais a caminho do matadouro. (Beckett, 2010, p.31)

Envelhecida, perdidos já quase inteiramente os traços da sua beleza de outrora, e anulados pela terra os atributos femininos do seu corpo, abandonada naquela tundra estéril sem qualquer apoio psicossocial e quase ignorada por Willie, a protagonista vai retirando do seu saco os poucos adereços que ainda a ligam a uma certa estética do corpo outrora belo e à comunidade humana (embora ausente), para além da linguagem, mesmo se já periclitante.

Da figuração desse desamparo físico e mental, em infindável reclusão, é parte integrante a terra a que as duas personagens se vão assimilando - metáfora geomórfica e simultaneamente metonímia da Natureza primordial e da sua impassível inumanidade. Ela constitui o elemento que na morte cobrirá todo o corpo, amalgamando-o, reduzindo-o por fim a si mesma, num rebaixamento último e radical 
que constitui o clímax de diversas situações ficcionais (cénicas ou narrativas) dominadas pela categoria do abjeto:

- [...] Comment continuer, je ne peux pas. Ah, me répandre par terre comme une bouse et ne plus bouger. Une grosse bouse couverte de poussière et de mouches, on viendrait m'enlever à la pelle. (2004, p.12)

Não sei por quanto tempo lá fiquei. Estava-se bem na caverna, devo dizer. Tratei os meus piolhos com água do mar e algas, mas muitas lêndeas devem ter sobrevivido. [...] De repente, voltou-se e atirou-se a mim. Olhem-me para aquele farrapo, clamou ele, para aquele refugo. Se não anda por aí de gatas é por ter medo da carroça da Câmara. Para o lixo, velho, piolhoso, infecto. Há mil iguais a ele, piores do que ele, dez mil, vinte mil. $\left(2006\right.$, p.67, 74-75) ${ }^{4}$

Trata-se de um discurso que figura as personagens desfigurando-as, ${ }^{5}$ rebaixando-as até ao insólito na sua vertente abjeta. Quase todos os protagonistas das suas Novelas são, aliás, proscritos pela sociedade, condenados a uma perpétua errância pelos espaços da sua indigência, cujas figurações vão desde os andrajos e a nudez ao habitáculo animal (currais, capoeiras, grutas); das posturas disformes, aproximando-as por vezes da condição reptiliana, às feridas ou pústulas de um corpo sofrido, impotente, quase inerte.

4 Estes excertos e tantos outros levam Élisabeth Angel-Perez a considerar a produção ficcional beckettiana como paradigmática da criação literária do pós-Auschwitz, referindo-se designadamente às suas obras teatrais, em particular, como paradigmáticas dos "teatros do traumatismo", embora o seu autor recorra simultaneamente a uma "estética da tortura" e à força expressiva do vazio, da ausência; numa palavra, da elipse como forma de "matérialisation de l'angoisse et de la douleur qui ne peut en aucun cas susciter de jouissance de la part du spectateur" $(2006$, p.45)

5 Sobre a noção de "Figuração desfiguradora" e suas relações com outros tópicos da temática aqui em estudo, veja-se Évelyne Grossman, 2004, p.115 
Na obra Malone está a morrer, o narrador autodiegético está confinado a uma cama, assistido precariamente por mãos anónimas e privado de qualquer diálogo ou interação com seres humanos. Uma vez mais, o corpo é (des)figurado sem alusão aos traços ou expressões do rosto - esse marcador identitário por excelência-, rebaixado a uma elementaridade de funções quase animal e designado como "carne estúpida" da qual o espírito se deve resguardar e abstrair, se possível (2003, p.15-18), amaldiçoada presumivelmente por um demiurgo malévolo, numa sugestão que nos aproxima do maniqueísmo da cosmogonia gnóstica. ${ }^{6}$

$\mathrm{Na}$ realidade, existe uma clara vertente inumana na dimensão metafísica que fundamenta a obra ficcional de Beckett, materializando-se numa perspetiva abjecionista do ser humano onde é ínfimo o lugar para a esperança. Sobressai, pelo contrário, um desprezo não isento de repugnância pela sua dimensão mais terráquea e visceral, a qual se projeta também claramente em atitudes e comentários face ao outro.

Daí que relativamente a estes corpos, enquanto as alusões à indumentária e acessórios são muito raras, a dimensão biológica seja tão massiva - das necessidades alimentares aos elementos escatológicos - constituindo uma outra vertente do insólito e do estranho, até à abjeção. E tal como é incontornável a dimensão biológica, também essa abjeção psicológica se revela intransponível ou sequer abordável pela introspeção crítica.

6 Para além da leitura de Nascimento Rosa, existe uma outra interpretação gnóstica da perspetiva beckettiana dualista e pessimista do mundo da Criação, bastante relevante para a compreensão deste aspeto em inúmeras figurações do corpo na obra do autor irlandês: veja-se Harold Bloom, $O$ cânone Ocidental. Os Livros e a Escola das Idades. Lisboa, Ed. Temas e Debates,1997 
O retrato do humano enquanto víscera vermiforme e pulsátil insere-se no projecto de redução ao elementar, ao digestivo e excremencial, a que Beckett nunca renuncia na sua obra, num exercício metódico de rebaixamento da imagem da espécie que somos, exercício análogo às espirituais preparações que Inácio de Loyola receitou aos neófitos da sua Companhia. [...] Mas em Beckett, o sentimento de culpa inculcado pela ortodoxia é vão, porque o indivíduo se mostra amputado de uma dimensão autónoma capaz de ser chamada à responsabilidade. (NASCIMENTO ROSA, 2000, p.53)

Insólitas igualmente, portanto, na sua abjeção mental, estas personagens são-no quase por via de uma força bruta, elementar e insuscetível de qualquer ordem de sublimação ou de coação ética, eclodindo livremente à semelhança da fatalidade que recai sobre as espécies animais e selvagens. Quando muito, elas surgem como marionetas do determinismo vital (de linhagem schopenhaueriana) ou de circunstâncias aleatórias, face às quais toda e qualquer vontade incipiente bem depressa soçobra em impotência e inércia. Vejam-se, nestas circunstâncias, personagens como Joe, em Dis Joe; Monsieur Rooney, em Tous ceux qui tombent; Homme, em Comédie; Louis Gordo, em Malone está a morrer ou o narrador da novela $O$ Banido, em Novelas e Textos para nada:

Bem gostaria de a ter atropelado, detesto crianças, aliás até Ihe faria um favor, mas receava as represálias. Toda a gente é pai, e é isso que nos proíbe de ter esperança. Dever-se-ia construir, nas ruas pedonais, pistas reservadas para esses seres malditos [...] para toda a sua maldita felicidade. Portanto, caí e a minha queda provocou a queda de uma velha, [...] Eu tinha esperança de que ela tivesse partido o fémur, que as velhas partem 
facilmente o fémur, mas não tão facilmente como isso. (2006, p.16-17)

Ainda outro aspeto do rebaixamento insólito do corpo diz respeito à privação alimentar a que este é sujeito com frequência, mantendo-se as personagens amiúde em situação de carência extrema. Devido a essa circunstância, serão levadas a recorrer a alimentos preferencialmente destinados aos animais: nabos, beterrabas, cenouras cruas, por exemplo.

Uma situação desta natureza torna ainda mais extrema a dependência da procura da matéria alimentar constitutiva da subsistência quotidiana, contribuindo para criar maiores afinidades ainda com as condições da vida animal, ao mesmo tempo que limita a atividade mental das personagens, bem como a sua inserção interventiva e plena numa dada comunidade social.

Com efeito, uma existência refém da mera arbitrariedade na obtenção de bens de subsistência tem como corolário a figuração de um corpo humilhado, rebaixado amiúde até à abjeção, para além de se constituir como cárcere das faculdades mais nobres do ser humano, aquelas que o distinguem claramente da condição de animalidade e que nestes textos são quase sistematicamente confiscadas.

Um dia, não consegui levantar-me. A vaca salvoume. Espicaçada pelo nevoeiro glacial, vinha abrigar-se. [...] Tirei o chapéu e pus-me a ordenhála para dentro da copa, apelando para as minhas derradeiras forças. [...] A vaca arrastou-me pelo soalho, parando apenas de tempos a tempos para me dar um coice. [...] Uma vez na estrada, só tinha de seguir a ladeira. Não tardaram a aparecer carroças, mas todas me recusaram. Se tivesse outra roupa, outra cara, talvez me tivessem deixado subir. [...] 
A cara, essa, já devia ter atingido o seu estado crítico. Já não havia sorriso humilde e ingénuo, nem a expressão de miséria cândida. [...] Máscara de couro sujo e peludo, já não queria dizer se faz favor e obrigado e desculpe. Era uma desgraça. Com que iria eu rastejar, de futuro? (BECKETT, 2006, p.69-70)

A figuração do corpo humano faminto, e em urgente atividade de satisfação de uma das suas necessidades básicas, denega, ou pelo menos obnubila, uma das mais importantes conquistas da passagem da condição animal à condição humana, conquistas que a antropologia de Lévi-Strauss, por exemplo, identificou e analisou. Elas relacionam-se com um facto que parece incontestável no processo civilizacional da "hominização": o de recusar dar simplesmente, acriticamente livre curso aos instintos ou necessidades naturais, ou seja, sem a intermediação de regras, limites, valores ou mesmo, em certos casos, tabus; numa palavra, de um modus operandi que se inclui globalmente no processo educacional do ser humano, no contexto de uma sociedade superiormente organizada.

Ora, quer nas obras aqui em foco, quer na ficção beckettiana em geral, é notória a ausência de personagens nesse contexto tão caro aos autores realistas: a refeição em comum, a degustação aprazível de pratos preparados de acordo com determinadas regras gastronómicas e acompanhada, regra geral, pelo gosto da convivialidade, a partilha ou discussão de ideias, acontecimentos, sentimentos, entre outros domínios da conversação, seja em registo burguês e mais ou menos culto, seja em registo popular.

Na verdade, mais do que tomar refeições, estas personagens eliminam a fome como podem: de pé, em trânsito para outro lugar qualquer, por vezes recorrendo a produtos recolhidos em hortas 
ou pomares; noutras situações, as personagens, imobilizadas e dependentes, recebem os alimentos de mãos anónimas, esperando sem quaisquer horizontes a chegada do dia final:

As coisas agora passam-se assim. A porta entreabre-se, uma mão poisa um prato na mesinha que aqui está para esse efeito, leva o prato da véspera e a porta volta a fechar-se. [...] O essencial é a alimentação e a eliminação, se se quiser aguentar. Bacio, gamela, são estes os dois polos. (BECKETT, 2003, p.15-16)

Ato de sobrevivência elementar, realizado lenta ou vorazmente, a alimentação não constitui senão uma necessidade "animal" do corpo, sendo portanto excluída enquanto circunstância propícia à socialização, ao refinamento de costumes e ao aprofundamento da civilidade.

Por seu lado, e numa espécie de paralelismo simétrico, o corpo sexuado e sexual adquire características bastante insólitas: ou surgem personagens nas quais a sexualidade parece estar inteiramente ausente e não ter qualquer relevância - Winnie e Willie, o casal Rooney - , ou outras que dela guardam somente recordações traumáticas - Malone, a mulher de Louis Gordo, várias personagens das Novelas, ou, finalmente, aquelas cujas práticas sexuais se assemelham muito às que se encontram no mundo animal - Joe, Homme, Louis Gordo e seus familiares.

Com efeito, as relações mantidas entre personagens femininas e masculinas são massivamente, nestas e noutras obras do autor, disfóricas e traumáticas ou, em alternativa, meros encontros fortuitos e aleatórios, com a exclusiva finalidade de satisfazer pulsões genésicas, numa atividade destituída de qualquer 
sentimento ou afeto e figurada em cruas imagens de bestialidade. Além disso, essa pesada negatividade das relações entre sexos está presente, seja na verbalização acusatória ou recriminatória assumida pelas personagens, seja por meio de uma constatação triste mas conformada, seja, enfim, através da voz implacável de um narrador autodiegético, confrontando o leitor com episódios de natureza sexual de brutal primitivismo.

Neste contexto, nem mesmo a prática do incesto (ou o seu desejo vívido) está ausente. Na verdade, constituindo estas personagens inequivocamente, também, figurações metafóricas do impressionante colapso civilizacional contemporâneo do seu autor, nelas irrompe a violência libidinal própria da barbárie, sem coações éticas de qualquer ordem, sem respeito pela alteridade e o arbítrio do outro e, no limite, recorrendo à violência sobre o corpo que se Ihe opõe ou recusa.

Louis fazia com que o temessem e comportavase como bem lhe dava na gana. [...] E ao mais pequeno sinal de revolta da parte dela, ele ia ao lavadouro buscar a pá de bater e espancava-a até ela reconsiderar. (BECKETT, 2003, p.40-41)

Mas que virá a ser dela? Disse eu. De quem? Disse ele. Da Pauline, disse eu. Vai envelhecer, disse ele, com uma certeza tranquila, primeiro lentamente, depois cada vez mais depressa, no meio de dores e rancores, comendo o pão que o Diabo amassou. [...] Bruscamente, a sua mão caiu-me sobre a nuca, os dedos vigorosos fecharam-se e com um safanão atraiu-me a si. (BECKETT, 2006, p.46-47)

Através da violência sexual e física sobre o corpo do outro, nenhum erotismo é sequer possível, assim como a mais incipiente 
consciência da transgressão de interditos (o incesto ou o estupro). Na verdade, conceitos e práticas como o erotismo, a transgressão, o interdito ou o tabu requerem um certo grau de elaboração e/ ou sofisticação civilizacional que está inteiramente ausente nestas personagens. Os seus corpos são inteiramente movidos por instintos primitivos - máquinas pulsionais que se abatem sobre as suas "presas", dotadas de corpos e mentes sem recursos para os neutralizar.

Compreende-se porventura mais claramente o abismo que separa o amor erotizado dessa não-reserva das pulsões predatórias, desse não-respeito pela integridade/dignidade do corpo do outro, ao acompanharmos a reflexão de Georges Bataille numa obra já clássica, escrita em torno de algumas destas questões:

Le renoncement du proche parent - la réserve de celui qui s'interdit la chose même qui lui appartient - définit l'attitude humaine, tout à l'opposé de la voracité animale. [...] II n'y aurait pas d'érotisme s'il n'y avait en contrepartie le respect des valeurs interdites (II n'y aurait pas de plein respect, si l'écart érotique n'était ni possible, ni séduisant.) Le respect n'est sans doute que le détour de la violence. D'un côté, le respect ordonne le milieu où la violence est interdite; de l'autre, il ouvre à la violence une possibilite d'irruption incongrue dans des domaines où elle a cessé d'être admise. L'interdit ne change pas la violence de l'activité sexuelle, mais il ouvre à l'homme discipliné une porte à laquelle l'animalité ne saurait accéder, celle de la transgréssion de la règle. $\left(1957\right.$, p.243) ${ }^{7}$

7 Nesta obra, intitulada L'Érotisme, Bataille parte dos notáveis estudos levados a cabo pelo antropólogo Claude Lévi-Strauss, nos quais este aprofunda as aquisições mais relevantes na evolução da animalidade para a " hominização", designadamente nas relações do ser humano com o próprio corpo, a sexualidade e o corpo do outro. Considerando a importância decisiva das observações e análises lévi-straussianas, Bataille aprofundará aqui o universo complexo e polifacetado do fenómeno erótico nas relações entre os sexos. 
Uma última característica das figurações do corpo insólito, na modalidade de rebaixamento, está metonimicamente associada ao espaço em que as personagens usam da palavra ou simplesmente se recolhem nas pausas da sua errância.

"Prolongamento da personagem", "lugar de alienação" ou " espaço-prisão" - segundo a designação de Marie-Claude Hubert (1987, p.91-93), o espaço é aqui figurado de modo a subverter as suas representações na ficção literária realista e naturalista, já que ele não tem como finalidade dar a ver ao leitor/espectador e caracterizar explicitamente estratos sócio-culturais ou contextos histórico-geográficos, sendo fundamentalmente metáfora dos destinos disfóricos e alienados das personagens, prisioneiras antes de tudo dos seus próprios corpos e, correlativamente, do espaço físico que prolonga e fixa as suas insuperáveis limitações.

Com efeito, o espaço e os seus adereços são figurados de modo a funcionar como uma espécie de "hiper-personagem", expandindo-a física e metaforicamente, quer com recurso aos adereços carcerários atrás considerados, quer a campos abertos, verdadeiras terras de ninguém; em alternativa, surgem ainda recintos ruinosos ou tugúrios repulsivos, aproveitados temporariamente pelos semabrigo, ou pelos proscritos da sociedade devido a comportamentos considerados desviantes ou, enfim, por não poderem ajustar-se às suas estruturas de funcionamento.

Aquilo a que ele chamava cabana era uma espécie de barraca de madeira. Tinham tirado a porta, para fazer uma fogueira, ou para qualquer outro fim. A janela já não tinha vidraça. O telhado tinha abatido em vários sítios. O interior estava dividido, pelos restos de um tabique, em duas 
partes desiguais. Se tinha havido móveis, já não havia nenhum. Alguém se tinha entregue aos actos mais abjectos, no chão e contra as paredes. [...] Era aquela a habitação cuja chave me tinham oferecido. (BECKETT, 2006, p.68-69)

Todas estas figurações do corpo insólito, em sentido lato, produzem no recetor um acentuado efeito de estranheza, adensado alternada ou cumulativamente por algumas das suas modalidades mais extremas, tais como o abjeto, o repulsivo e/ou o repugnante.

Porém, se é verdade que personagens e situações são com frequência equivalentes e as condições físicas dos seus corpos ciclicamente distópicas ou disfuncionais, essas constantes não as transformam em personagens-tipo, tal como as conhecemos nos contextos periodológicos do Romantismo ou do Realismo, por exemplo, com os seus modelos representacionais próprios e de molde a corresponderem a tipos psicossociais que o recetor facilmente reconhece como relativamente familiares e classificáveis, porque de algum modo correspondem a categorias específicas e distintas de personagens com forte enraizamento no contexto ou no horizonte de expectativa desse mesmo recetor.

Num dos seus textos consagrados a esta questão, escreve Carlos Reis:

Tenha-se em conta desde já que o tipo deve ser entendido como uma subcategoria da personagem, emergindo a sua figuração em tempos literários e ideológicos que justificam a sua presença. [...] Sendo assim, o tipo, apresentando-se embora como figura individualizada (com nome próprio, para nos entendermos), não perde contacto com um 
coletivo em que se insere e com dominantes sociais e psicológicas desse coletivo. [...] A nossa perceção do tipo contempla, então, propriedades sociais, psicológicas ou físicas que podemos sumariar num só vocábulo ou numa frase curta: o agiota, o avarento, o jornalista são, então, emblemas de profissão, de mentalidade ou de classe social que, uma vez reconhecidos como tais, impedem a surpresa, no que toca aos seus comportamentos numa ação narrativa [...] Do que fica dito resulta o seguinte: o tipo, enquanto personagem que age de forma redundante e previsível, dificulta ou atá inviabiliza o insólito; é contra o típico que o insólito ousa afirmar-se como tal. A isto acrescento o seguinte: não sendo exclusivo do realismo, é sobretudo nele que o tipo acentua o potencial de crítica social que lhe é inerente. (2015, p.105-106)

Convencionalidade e previsibilidade são, por conseguinte, dois atributos próprios das personagens-tipo e antagónicos da categoria do insólito, bem como das suas variantes ou modalidades consideradas neste estudo (do estranho ao abjeto ou ao repugnante). Como tal, eles situam-se fora da órbita das personagens beckettianas, que têm essencialmente como desígnio figurar metaforicamente a condição humana, sobretudo nesse mundo "pós-ético" ou "pós-Auschwitz" que assombrava a humanidade de então. Por outras palavras, estas personagens pertencem a uma escala que está para além da sua origem geográfica, do seu meio sócio-económico e/ou cultural (amiúde neutros ou indiferenciados) ou de outros aspetos imprescindíveis na figuração de personagens-tipo.

Eis por que, não obstante o humor negro e/ou farsesco tão recorrente nas obras em estudo, nestas opera-se simultaneamente 
uma transgressão desconstrutiva da pragmática utilitária patente no texto cómico ou paródico convencional, o qual partilha registo "morigerador" e registo lúdico.

Enfim, longe de ser uma obra de entretenimento de um público mais ou menos burguês ou conservador nos seus horizontes estético-literários, nela dificilmente o coletivo humano se revê de forma imediata. Somente numa especularidade física e metaforicamente deformante - de que o corpo, no seu hiperbólico rebaixamento mas também na sua inegável humanidade, é claramente o protagonista omnipresente - , a sua leitura se torna viável e frutífera.

É nesse sentido que deveríamos entender as marcantes palavras de Élisabeth Angel-Perez:

[...] dans ce monde post-éthique [...] le corps beckettien, comme le corps du déporté, est également celui pour qui la capacité à pleurer est la marque indéféctible de son humanité. [...] Chez Beckett, le corps deshumanisé, animalisé [...] contraste avec le corps, paradoxalement précieux à I'occasion, maintenu en souffrance. (2006, p.31-32)

$\mathrm{Na}$ verdade, risíveis ou pungentes, ou tudo isso indissociavelmente ligado e significante, estas personagens e, de modo muito particular, as figurações dos seus corpos insólitos, deixam no leitor/espectador uma inolvidável ressonância, constituindo-se ao mesmo tempo como um memorial a um mundo sob muitos aspetos "pós-ético", cujo legado ainda hoje nos assombra e ensombra. 


\section{REFERÊNCIAS}

ABIRACHED, Robert (1978). La Crise du Personnage dans le Théâtre moderne. Paris: Ed. Grasset.

ADORNO, Theodor W. (2008). Notes sur Beckett. Caen: Ed. Nous.

ANGEL-PEREZ, Élisabeth (2006). Voyages au bout du possible: Les Théâtres du Traumatisme de Samuel Beckett à Sarah Kane. Paris: Ed. Klincksieck.

ANZIEU, Didier (1996). "Sur Beckett". In: Créer Détruire. Paris: Dunod.

BATAILLE, Georges (1957). L'Érotisme. Paris: Ed. De Minuit.

BECKETT, Samuel (1972). “Dis Joe”. In: Comédie et Actes divers. Paris: Ed. De Minuit. . (1972). "Acte sans Paroles II". In: Comédie et Actes divers. Paris: Ed. De Minuit.

. (1972). "Comédie". In: Comédie et Actes divers. Paris: Ed. De Minuit. . (2004). Tous ceux qui tombent. Paris: Ed. De Minuit. . (2010). Dias Felizes. Lisboa: Ed. Estampa.

. (2003). Malone está a morrer. Lisboa: Ed. Dom Quixote. . (2006). Novelas e Textos para Nada. Lisboa: Ed. Assírio \& Alvim.

CURTIS, Jerry L. (1994). "Samuel Beckett's Claustrophobic Prisoners". In: The Imprisoned Hero in Camus, Beckett, and Desvignes. Knoxville: New Paradigm Press. GROSSMAN, Évelyne (2004). La Défiguration. Paris: Ed. du Seuil.

HUBERT, Marie-Claude (1987). Langage et Corps fantasmé dans le Théâtre des années cinquante. Paris: Libr. José Corti.

REIS, Carlos (2015). Pessoas de Livro: Estudos sobre a Personagem, caps.1,3,4,5. Coimbra: Imprensa da Universidade de Coimbra. . (2006). "Narratologia(s) e teoria da Personagem". In: REIS, Carlos (coord.). Figuras da Fiç̧ão. Coimbra: Centro de Literatura Portuguesa, FLUC. ROSA, Armando Nascimento (2000). Falar no Deserto: Estética e Psicologia em Samuel Beckett. Lisboa: Ed. Cosmos. 